\title{
РАСПРОСТРАНЕНИЕ НЕКОТОРЫХ ИНГРЕДИЕНТОВ ОТХОДОВ ЖИВОТНОВОДСТВА В МОРЕННЫХ ГРУНТАХ ЭСТОНИИ
}

E. JOHANNES, $P$, JOGAR, P. KILDER. MONINGATE POLLUMAJANDUSREOSTUSE KOMPONENTIDE LEVIK EESTI MOREENPINNASTES

E. JOHANNES, P. JOGAR, $P$. KILDER. THE DISTRIBUTION OF AGRICULTURAL POLLUTION INGREDIENTS IN ESTONIAN MORAINE SOILS

В условиях интенсивного животноводства в Эстонской ССР наибольшую опасность для окружающей среды, в том числе и для подземных вод представляют жидкие отходы животноводства - навозная жижа и жидкий навоз (Maastik, 1978). Проникновение ингредиентов навоза из навозохранилищ в моренные грунты Эстонии мало изучено. В зоне аэрации эти грунты играют значительную роль в защите подземных вод от загрязнения.

В целях изучения распространения некоторых ингредиентов навоза в 1978-1979 гг. при помощи агрегата вибрационного бурения были отобраны 79 проб моренных суглинков и супесей из 19 скважин, находящихся у навозохранилищ 13 ферм крупного рогатого скота, а также 16 образцов флювиогляциальных песков из 3 скважин у навозохранилищ 3 ферм. Образцы морен отбирались из зоны аэрации с глубины $0,5-5,0$, образцы песков - с глубины $0,8-3,6 м$ в расстоянии $1-20 \mu$ от навозохранилищ. Эти образцы в основном принадлежат к светло-серым супесчаным моренам Северной Эстонии со сравнительно высоким содержанием галек, гравия и валунов (в 16 скважинах около 11 ферм). Остальные моренные образцы представляют собой красноцветную супесчаную породу Южной Эстонии с относительно небольшим количеством галек и гравия.

Для характеристики распространения ингредиентов в 29 образцах морен были определены средневзвешенный состав и число пластично-
сти их.

В качестве изучаемых ингредиентов служили органическое вещество и нитрат-ионы $\left(\mathrm{C}_{\text {opr. }}\right.$ и $\left.\mathrm{NO}_{3}^{-}\right)$. Следует отметить, что миграция соединений азота (аммиачного, гидролизуемого, подвижного и фиксированного), а также органического вещества является предметом исследований и в почвоведении (до глубины 0,8-1,0 м). Содержание азота в почве в природных условиях с глубиной, как правило, уменьшается (Роосталу, 1971). Органическое вещество, образовавшееся в почве, аккумулируется в ней и только незначительная часть его подвергается миграции (Рейнтам, Роома, 1969). Поэтому в природных условиях эти вещества в моренах и песках почти не содержатся, однако при загрязнении грунта они сразу же обнаруживаются.

Содержание органического вещества, выраженного в процентах органического углерода, определялось в грунтах путем его окисления бихроматом калия и титрования избытка раствором соли Мора (Бирюков и др., 1975), содержание нитрат-иона (мг/100 г сухого грунта) ды... 1973) из водной вытяжки. В исследованной выборке образцов 


\begin{tabular}{|c|c|c|c|c|c|c|}
\hline \multirow{3}{*}{$y$} & & & $x$ & & & \\
\hline & \multirow{2}{*}{$\begin{array}{c}\text { Глубина } \\
\text { отбора } \\
\text { образцов, } \\
\text { м }\end{array}$} & \multirow{2}{*}{$\begin{array}{l}\text { Средневзве- } \\
\text { шенный гра- } \\
\text { нулометриче- } \\
\text { ский состав }\end{array}$} & \multirow{2}{*}{$\begin{array}{l}\text { Число } \\
\text { пластич- } \\
\text { ности }\end{array}$} & \multicolumn{3}{|c|}{$\begin{array}{c}\text { Расстояние от очага } \\
\text { нения, } \boldsymbol{M}\end{array}$} \\
\hline & & & & $\begin{array}{c}\text { на глубине } \\
0-1 M\end{array}$ & $\begin{array}{c}\text { на глубнне } \\
1-2 \mu\end{array}$ & $\begin{array}{c}\text { на глубине } \\
>2 \stackrel{\mu}{ }\end{array}$ \\
\hline
\end{tabular}

Морены

\begin{tabular}{|c|c|c|c|c|c|c|}
\hline $\mathrm{NO}_{3}^{-}, \mathrm{Me} / 100 \mathrm{e}$ & $\begin{array}{c}-0,275 \\
y=a x+b\end{array}$ & $\begin{array}{c}0,40 \\
y=a \log x+b\end{array}$ & $y=a^{-0,22} \log x+b$ & $\begin{array}{c}-0,11 \\
y=a x^{2}+b\end{array}$ & $\begin{array}{c}-0,16 \\
y=a x^{2}+b\end{array}$ & $\begin{array}{c}-0,30 \\
y=a x^{2}+b\end{array}$ \\
\hline $\mathrm{C}_{\text {opr }}, \%$ & $\begin{array}{c}0,05 \\
y=a e x+b\end{array}$ & $y=a \log x+b$ & $\begin{array}{c}-0,02 \\
y=a e^{x}+b\end{array}$ & $\begin{array}{c}-0,14 \\
y=a x^{2}+b\end{array}$ & $\begin{array}{c}-0,13 \\
y=a e x+b\end{array}$ & $\begin{array}{c}-0,09 \\
y=a \log x+b\end{array}$ \\
\hline
\end{tabular}

Пески

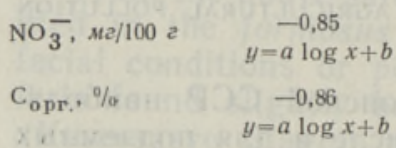

$$
\begin{gathered}
-0,66 \\
y=a e x+b \\
-0,87 \\
y=a e x+b
\end{gathered}
$$

морен и песков содержание органического углерода находится в пределах $0,05-1,7 \%$, нитрат-иона - $0,1-12,5$ мг на 100 г сухого грунта. Как правило, уменьшение содержания ингредиентов по мере увеличения глубины трудно улавливается, поэтому для определения зако: номерностей распространения их в грунтах использовались специальные приемы анализа регрессии. Проведено исследование типов регрессионных кривых линейной модели

$$
y=a x+b,
$$

где в качестве $x$ использованы различные функции от значения глубины отбора образцов, гранулометрического состава и пластичности, а также расстояния от очага загрязнения. Определялся тип кривой регрессии, гарантирующий наилучшее приближение к результатам анализов ингредиентов. С помощью коэффициента корреляции определялась степень соответствия интенсивности распространения ингредиентов общепринятыми модельными представлениями: чем глубже и дальше от очага загрязнения, тем меньше обнаруживается в грунте ингредиентов.

Результаты анализов, отдельно по моренам и флювиогляциальным пескам, приведены в таблице, откуда видно, что:

1) поведение ингредиентов $\mathrm{NO}_{3}^{-}$и $\mathrm{C}_{\text {орг. }}$ в моренах и в песках резко различается (для песков коррелятивные связи более тесные, чем для морен);

2) поведение обоих ингредиентов в моренах также значительно раз. личается (распространение ингредиента $\mathrm{C}_{\text {opr. }}$ хуже соответствует модели);

3) чем больше средневзвешенный гранулометрический состав морен, тем лучше она пропускает ингредиенты, и чем пластичнее грунт, тем хуже его пропускная способность.

Анализ регрессионных кривых позволяет рассчитать границы распространения ингредиентов до достижения ими природного фона на уровне $95 \%$-ной обеспеченности. По данным настоящей выборки, ингредиент $\mathrm{NO}_{3}^{-}$распространяется до глубины 1,8 $м$ в моренах и 2,25 в песках (от кров̈ли морены или песков) и нриблизительно на расстоянии $12, \mu$ от навозохранилища (в моренах). Ингредиент $\mathrm{C}_{\text {opr }}$ характеризуется приблизительно такими же величинами. 


\section{ЛИТЕРА Т У РА}

Бирюков Н. С., Казарновский В. Д., Матылев Ю. Л. Методическое пособие по определению физико-механнческих свойств' грунтов. М., 1975.

Р ей н т а Л., Р о ом а И. О миграции органического вещества, железа и кальция в некоторых почвах Эстонии. - Сб. научных трудов ЭСХА, 1969, 62, 34-51.

Р оосталу X. Содержание и связи азота в некоторых почвах Эстонской ССР. Сб. научных трудов ЭСХА, 1971, 73, 3-118.

Унифицированные методы анализа вод. М., 1973.

M a a st i k, A. Põllumajandus ja veekaitse. - Rmt.: Põhjavee kasutamisest ja kaitsest Eesti NSV-s. Tln., 1978, 77-78.

\section{Ннститут геологии \\ Академии наук Эстонской ССР \\ Поступила в редакцию 29/VI 1981}

\section{Государственный проектный институт «Эстеипросельстрой»}

Ярозит - продукт современного гипергенеза в пористых алевролитах кембрия Эстонии. Пи р рус Э. - Изв. АН ЭстССР. Геология, 1982, т. 31 , № 1, с. $1-6$ (рез. эст., англ.)

Описываются находки ярозита в порах алевролитов нижнего кембрия в полосе их выхода на уступе Северо-Эстонского глинта. Ярозит формировался за счет продуктов окисления обильной вкрапленности пирита в этих нормально-морских осадочных породах, в которые эти вещества были перенесены в виде сульфатных растворов до зоны разгрузки грунтовых вод на глинте. Показано принципиальное совпадение зональности гипергенного минералообразования с гидрохимической зональностью грунтовых вод в районе глинта, а также указано на возможное усиление процесса в результате деятельности человека на горнодобывающих предприятиях. Рнс, 2. Табл. 1. Бнбл. 8 назв.

\section{удК $56.016 .3: 551.73(474.2)$}

Вопросы стратиграфии и хиолительминты юлгазеских отложений Эстонии. Х а за нович К., Миссар жевский В. - Изв. АН ЭстССР. Геология, 1982, т. 31, № 1, c. 7 -11 (рез. эст., англ.)

Обращается внимание на вероятность позднекембрнйского возраста юлгазеской пачки, относимой в настоящее время к нижней части пакерортского горизонта тремадока. Предлагается рассматривать пачку в качестве самостоятельнои стратиграфической единицы в ранге свиты с подразделением ее на две литологические пачки - нижнюю и верхнюю. Приводится палеонтологическое описание нового вида хнолительминтов Torellella sulcata. Рис. 3. Табл. 1. Библ. 11 назв. 